\title{
Short Rotation Coppice (SRC) Plantations Provide Additional Habitats for Vascular Plant Species in Agricultural Mosaic Landscapes
}

\author{
Sarah Baum • Andreas Bolte • Martin Weih
}

Published online: 13 April 2012

(C) The Author(s) 2012. This article is published with open access at Springerlink.com

\begin{abstract}
Increasing loss of biodiversity in agricultural landscapes is often debated in the bioenergy context, especially with respect to non-traditional crops that can be grown for energy production in the future. As promising renewable energy source and additional landscape element, the potential role of short rotation coppice (SRC) plantations to biodiversity is of great interest. We studied plant species richness in eight landscapes $\left(225 \mathrm{~km}^{2}\right)$ containing willow and poplar SRC plantations $\left(1,600 \mathrm{~m}^{2}\right)$ in Sweden and Germany, and the related SRC $\alpha$-diversity to species richness in the landscapes ( $\gamma$-diversity). Using matrix variables, spatial analyses of SRC plantations and landscapes were performed to explain the contribution of SRC $\alpha$-diversity to $\gamma$-diversity. In accordance with the mosaic concept, multiple regression analyses revealed number of habitat types as a significant predictor for species richness: the higher the
\end{abstract}

\footnotetext{
S. Baum $(\triangle) \cdot$ A. Bolte

Institute for Forest Ecology and Forest Inventory,

Johann Heinrich von Thünen-Institute (vTI),

Alfred-Möller-Straße 1,

16225 Eberswalde, Germany

e-mail: sarah.baum@vti.bund.de

A. Bolte

e-mail: andreas.bolte@vti.bund.de

S. Baum $\cdot$ A. Bolte

Department of Silviculture and Forest Ecology of Temperate

Zones, Georg-August-University Göttingen,

Büsgenweg 1,

37077 Göttingen, Germany

M. Weih

Department of Crop Production Ecology,

Swedish University of Agricultural Sciences (SLU),

P.O. Box 7043, Ulls väg 16,

75007 Uppsala, Sweden

e-mail: martin.weih@slu.se
}

habitat type number, the higher the $\gamma$-diversity and the lower the proportion of SRC plantation $\alpha$-diversity to $\gamma$-diversity. SRC plantation $\alpha$-diversity was $6.9 \%( \pm 1.7 \% \mathrm{SD})$ of species richness on the landscape scale. The contribution of SRC plantations increased with decreasing $\gamma$-diversity. SRC plantations were dominated more by species adapted to frequent disturbances and anthropo-zoogenic impacts than surrounding landscapes. We conclude that by providing habitats for plants with different requirements, SRC $\alpha$-diversity has a significant share on $\gamma$-diversity in rural areas and can promote diversity in landscapes with low habitat heterogeneity and low species pools. However, plant diversity enrichment is mainly due to additional species typically present in disturbed and anthropogenic environments.

Keywords Agriculture · Biodiversity · Bioenergy · Poplar (Populus) $\cdot$ Structural heterogeneity · Willow (Salix)

\section{Introduction}

Against the background of global biodiversity loss largely caused by intensive agriculture [1-5], the diversity of entire agricultural landscapes, the $\gamma$-diversity, is of great research interest. The $\gamma$-diversity addresses the species diversity of a landscape with more than one kind of natural community, and it includes the diversity within ( $\alpha$-diversity) and among communities ( $\beta$-diversity, terminology of Whittaker [6]). Unlike species richness, species diversity takes the proportional abundances of species into account [7]. Many scientific papers address the question of the importance of structural heterogeneity in agricultural landscapes and agree that landscape heterogeneity is beneficial for biodiversity [i.e. 8-12]. According to Forman [13], a matrix of large patches of plant communities supplemented with small patches scattered throughout the 
landscape characterizes an optimum landscape as small patches provide different benefits for biodiversity compared to large patches.

The cultivation of bioenergy crops as renewable energy source is debated widely [cf. 14-17]. To reach the EU target of producing $20 \%$ of the primary energy consumption from renewable energies in the year 2020, vast areas of land will be necessary for energy crop cultivation [18-20] for biomass production to be a promising option [i.e. 14, 21]. The large areas needed and economic cost of transporting raw biomass material to end-use locations raise concerns about large-scale biomass crop monocultures [18]. Short rotation coppice (SRC) plantations are perennial lignocellulosic energy crops with high biomass yields; they are expected to play a major role (together with perennial grasses like miscanthus, reed canary grass and giant reed) in increasing the amount of renewable energy from biomass in Europe [22, 23]. The potential contribution of SRC plantations to biodiversity as an additional landscape element in agricultural areas is described in various studies [e.g. 24-33], which reported predominantly positive effects.

The aim of our study is to analyse the suitability of SRC characteristics and landscape matrix characteristics for predicting the contribution of $\alpha$-diversity of SRC plantations to vascular plant $\gamma$-diversity in fragmented agricultural landscapes. As an alternative to the equilibrium theory of island biogeography by MacArthur and Wilson [34] and Duelli $[35,36]$ developed the mosaic concept for agricultural landscapes claiming habitat variability (number of biotope types per unit area), habitat heterogeneity (number of habitat patches and ecotone length per unit area) and the proportional area of natural (untouched), semi-natural (perennial vegetation or cultures with low input) and intensely cultivated areas (mainly annual crops and monoculture plantations) as the most suitable factors for predicting biodiversity of an agricultural mosaic landscape. Evidence for this theory was found by Simmering et al. [11]: while at the patch scale, habitat type, area and elongated shape were the main determinants of plant species richness, non-linear habitat richness, the gradient from anthropogenic to semi-natural vegetation and the proportions of natural vegetation and rare habitats were predictors for species richness at the multi-patch (1 ha each) scale, in a highly fragmented agricultural landscape in central Germany. A positive relationship between vascular plant species richness, number of habitat types and habitat patches per area was also found by Waldhardt et al. [12].

The plant species richness of willow and poplar SRC plantations smaller than 10 ha and grown for biomass energy was related to $\gamma$-diversity of the corresponding five Swedish and three German landscapes. In reference to the mosaic concept $[35,36]$, we explore the hypotheses that the share of SRC plantation $\alpha$-diversity on $\gamma$-diversity depends on (1) landscape structure and (2) $\gamma$-diversity itself. In contrast to landscapes with homogenous structures, we expect a higher $\gamma$-diversity but lower SRC plantation $\alpha$ diversity in areas with heterogeneous structures characterized by high numbers of habitats and habitat patches with long edges. Further, we expect a higher $\gamma$-diversity in areas with higher proportions of semi-natural vegetation and rare habitats, and a higher SRC plantation $\alpha$-diversity share in species-poorer landscapes than in species-richer ones.

\section{Material and Methods}

\section{Study Areas and Sites}

Our survey on plant species diversity was conducted on eight landscapes of $15 \times 15 \mathrm{~km}$, corresponding to $225 \mathrm{~km}^{2}$ surface area. Five areas were located in Central Sweden in the Uppland province and three in Northern Germany in the states of Brandenburg (one study area) and Lower Saxony (two study areas). We selected study areas (landscapes) in which SRC plantations were a representative element. Within each landscape, we chose one or several SRC plantations of 1 to $10 \mathrm{ha}$, and we delimited the landscapes so that the SRC plantations were situated centrally. We chose SRC plantations for which we had sufficient information regarding plant material and management history. The SRC plantations contained mainly willow clones but also poplars of various ages and rotation regimes. Former land uses also varied (for further descriptions of SRC study sites see Table 1). Due to overlaps with another research project we used four landscapes in which two SRC plantations each were considered (SRC study sites Franska/Kurth, Hjulsta, Lundby), and one landscape in which three SRC plantations were regarded (study sites Bohndorf I, II and III). The SRC plantations located in the same landscape cannot be considered independently in statistical analyses. Thus, we used mean species numbers, shoot ages and plantation ages for SRC plantations located in the same landscape.

The Swedish sites were exposed to lower temperatures and received less precipitation than the German sites: mean annual temperature was about $5.5^{\circ} \mathrm{C}$ for the Swedish study sites and $8.5^{\circ} \mathrm{C}$ for the German sites. During the growing season (May-September) mean monthly temperature was $13.5{ }^{\circ} \mathrm{C}$ for the Swedish and $15{ }^{\circ} \mathrm{C}$ for the German sites. Annual precipitation was about $530 \mathrm{~mm}$ (monthly mean during the growing season: $55 \mathrm{~mm}$ ) for the Swedish sites and about $640 \mathrm{~mm}$ (monthly mean during the growing season, $60 \mathrm{~mm}$ ) for the German sites (data bases: longterm recordings from 1961 to $1990[37,38])$.

The Swedish study sites were characterized by cohesive soils with high clay content. The bedrock is predominantly granite and gneiss. Sand deposits, which were covered with sandy soils, were the prevailing parent material at the German 


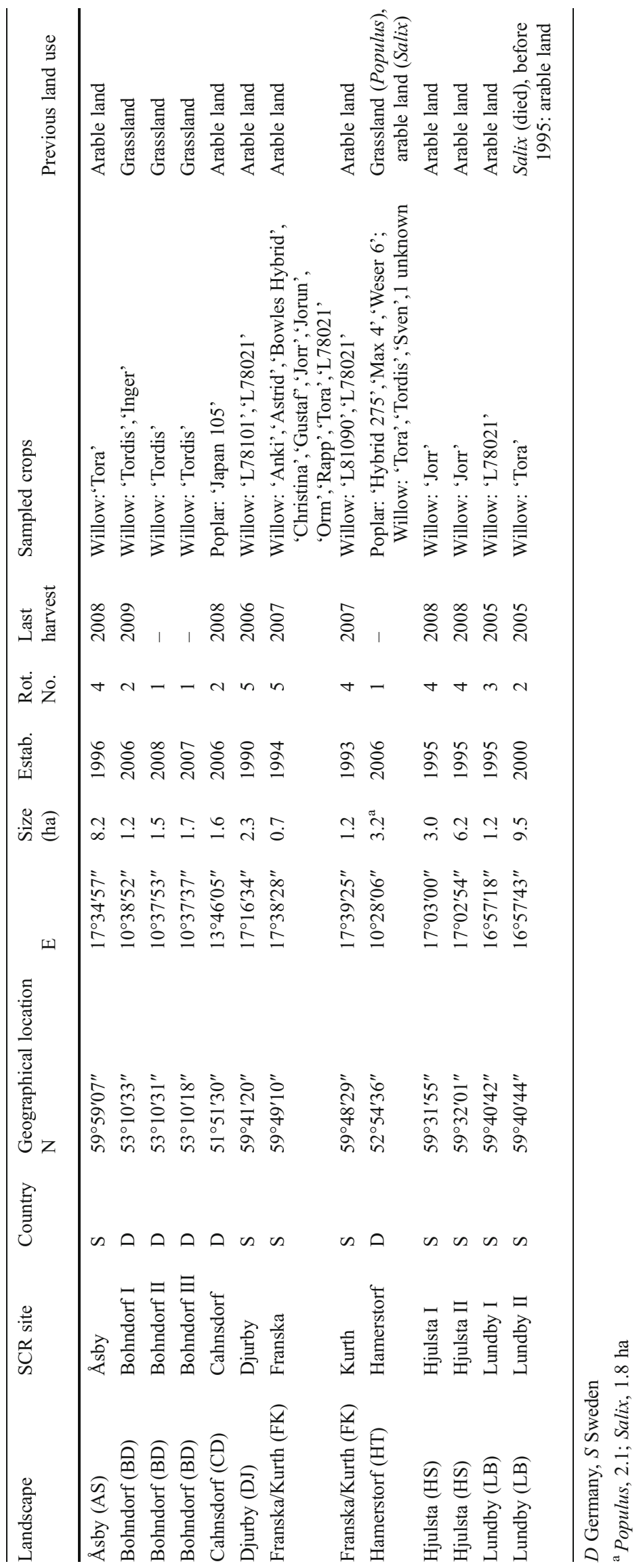


sites. The landscape structure is described in the result section under the subheading "Landscape structure and the landscape SRC diversity effect on $\gamma$-diversity".

\section{Spatial Analyses}

Spatial analyses were conducted to test how SRC plantations contribute to species diversity of the surrounding landscape and to look for structural elements that are indicative for the SRC contribution to landscape $\gamma$-diversity. The spatial scale $\gamma$-diversity referred to is not explicitly defined [7, 39], but Whittaker [40] distinguished $\gamma$-diversity (species diversity of a landscape comprising more than one community type) from $\varepsilon$-diversity that describes the diversity of geographical areas across climatic or geographic gradients. The reference area for $\gamma$-diversity is about $100 \mathrm{~km}^{2}$, but for $\varepsilon$ diversity it is about $10^{6} \mathrm{~km}^{2}$ [41]. We defined the landscape scale in terms of areas of $225 \mathrm{~km}^{2}$ for the evaluation of $\gamma$-diversity, and those areas were overlaid with CORINE (Coordinated Information on the European Environment) Land Cover data [42]. The availability of those data for both Sweden and Germany enabled us to evaluate structural landscape attributes on the same database. Base year for the land cover data was 2006. CORINE provides land cover data on three different levels [42]. Higher levels cumulate land cover classes of the lower level. The broadest classification is 'level 1' distinguishing the five land cover classes 'Artificial surfaces', 'Agricultural areas', 'Forest and semi-natural areas', 'Wetlands' and 'Water bodies'. All five classes of level 1 were present in our study areas. Twelve classes were present on level 2 and 21 on level 3 (Table 1).

\section{Floristic and SRC Vegetation Assessment}

For comparing SRC vegetation data with the diversity of the higher landscape scale, species lists from the nation-wide German floristic mapping [43] and region-wide Swedish mapping (for the province of Uppland) [44] were used. The data were provided by the German Federal Agency for Nature Conservation (BfN) and by the Swedish Species Information Centre (ArtDatabanken, SLU) for $5 \times 5$-km map excerpts. Nine map excerpts-one with the SRC in the centre, and eight bordering map excerpts - were used to determine the reference areas for the higher landscape scales in order to avoid any SRC being located close to the margin of the map area. The entire set of maps encompassed approximately $225 \mathrm{~km}^{2}$ area $(15 \times 15 \mathrm{~km})$. Flora species lists were simplified to species level to avoid overestimations.

SRC vascular plant species abundance was recorded in 2009 from May until July in Germany and from July until August in Sweden. At each SRC site, the species in 1,600 $\mathrm{m}^{2}$, corresponding to 144 plots of about $11 \mathrm{~m}^{2}$ size, were assessed in four $400 \mathrm{~m}^{2}$ areas $(20 \times 20 \mathrm{~m})$. For each plot a species list was compiled. The nomenclature follows Rothmaler [45].

\section{Data Analysis}

In a first step, species-area curves from SRC vegetation mappings were calculated to determine the minimum area for representative species numbers [46] and to test the representativeness of our $1,600 \mathrm{~m}^{2}$ plots for deriving SRC plantation $\alpha$-diversity values. For all area units (one plot to 144 plots), species numbers of all possible plot permutations [cf. 47] were calculated and averaged per unit area by EstimateS 8.2.0 [56].

In a second step, the relationship between the SRC diversity and the $\gamma$-diversity was investigated. A linear positive relationship would indicate that the share of SRC diversity on $\gamma$ diversity does not change with increasing $\gamma$-diversity. The contribution of SRC plantation $\alpha$-diversity to plant $\gamma$-diversity of the surrounding landscapes, defined here as 'landscape SRC diversity effect', was calculated by Eq. 1 where $\alpha$-diversity is the species number recorded in $1,600 \mathrm{~m}^{2} \mathrm{SRC}$ plantation, and $\gamma$ diversity is the species number found on landscape scale $\left(225 \mathrm{~km}^{2}\right)$.

landscape SRC - diversity effect $=\frac{\alpha-\text { diversity }}{\gamma-\text { diversity }}$

Linear regression analysis and test of homoscedasticity of residuals was applied using $\gamma$-diversity as predictor variable and landscape SRC diversity effect as response variable. To determine whether SRC variables and landscape matrix variables were significant predictors of the 'landscape SRC diversity effect' and of ' $\gamma$-diversity' (landscape matrix variables only, Fig. 1), multiple regression analysis was conducted. For the response variable ' $\gamma$-diversity', Poisson regression for count data was used (procedure PROC GENMOD, SAS 9.2)
Fig. 1 SRC variables and landscape matrix variables included in multiple regression analyses for the response variables 'landscape SRC diversity effect' and ' $\gamma$ diversity'. CLC class 2 agricultural areas, CLC class 3 forest and semi-natural areas

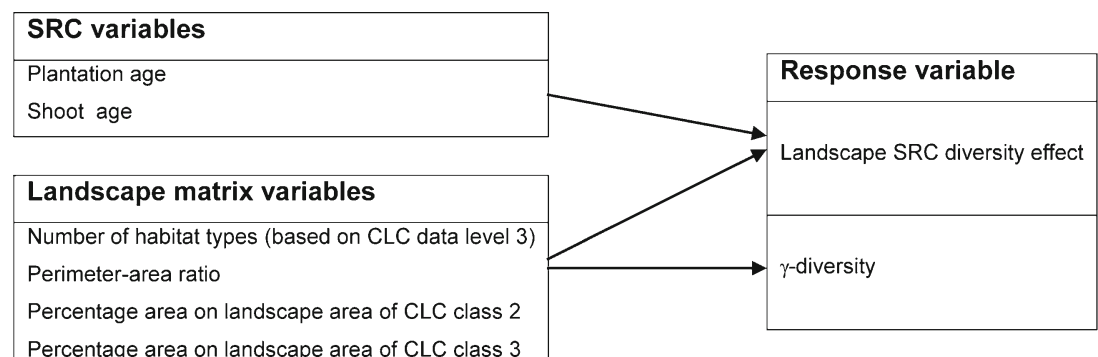

Percentage area on landscape area of CLC class 3 
and overdispersion was corrected by Pearson's $\chi^{2}$. The landscape matrix variable 'perimeter-area ratio' $(P$ : perimeter, $A$ : patch area, cf. [48]) was calculated by Eq. 2:

$P / A=\sum_{i=1}^{m} P_{i} / \sum_{i=1}^{m} A_{i}$

The decision on the best-fitted model was based on the Akaike information criterion (AIC), in which a smaller value indicates a better fit of a model. However, the AIC does not provide information on the absolute model fit, i.e. its significance has to be tested. Inter-correlations among explanatory variables were investigated with Pearson's product moment correlation. Since no significant correlations were found (significance level: $p<0.05$ ), multiplicative interactions were not included in multiple regression analysis.

To compare landscape SRC diversity effect and $\gamma$-diversity, the plants were assigned to plant communities according to Ellenberg et al. [49]. The Shapiro-Wilk test was applied to test the proportions of plant communities for normal distribution. For normally distributed data the $t$ test was applied to compare plant community proportions of SRC plantations with those of the landscape. For data not normally distributed the nonparametric Mann-Whitney $U$ test (two-sided) was chosen.

\section{Results}

Representativeness of SRC Vegetation Samplings and Its Relationship to Landscape $\gamma$-Diversity

The species-area curves validated our sample size of $1,600 \mathrm{~m}^{2}$ per SRC plantation as suitable for comparisons with the $\gamma$-diversity (Fig. 2). The increase in species number with area size slowed down rapidly from area sizes above

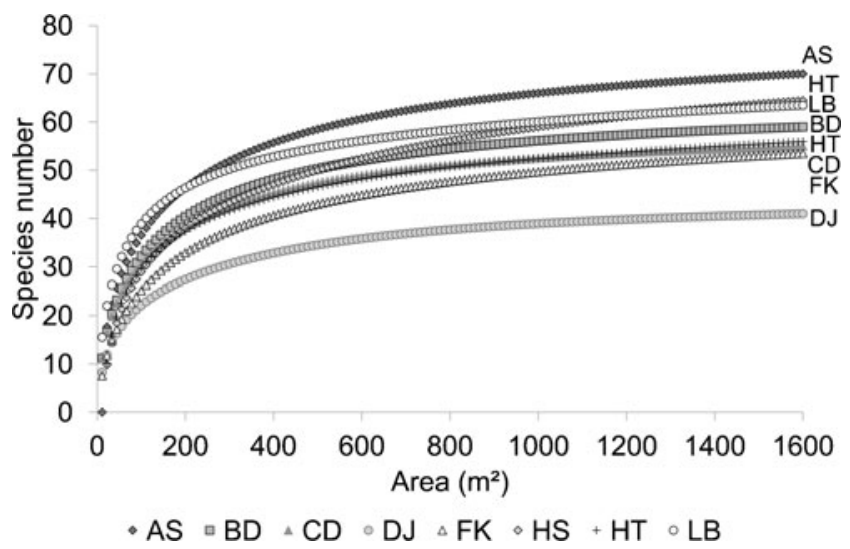

Fig. 2 Species-area curves of the SRC plantations. All possible permutations of the 144 plots per SRC plantation were calculated and averaged per area unit $\left(1 \mathrm{plot}=11.11 \mathrm{~m}^{2}\right)$. Abbreviations of SRC plantation names see Table 1 approximately $200-300 \mathrm{~m}^{2}$ sampled area. At areas between circa 600 and $1,000 \mathrm{~m}^{2}, 90 \%$ of the species recorded in $1,600 \mathrm{~m}^{2}$ were detected. As the sample size is representative, SRC plantation size was excluded from multiple regression analysis.

No linear relationship was found for SRC $\alpha$-diversity vs. landscape $\gamma$-diversity $\left(R^{2}=0.16, p=0.3290\right.$, Fig. 3a) indicating a variable contribution of SRC diversity to landscape diversity with increasing $\gamma$-diversity.

Landscape Structure and the Landscape SRC Diversity Effect on $\gamma$-Diversity

All study areas were dominated by non-irrigated arable land (34-58 \% land cover) and coniferous forests (19-31\% land cover, Table 2). With the exception of $30 \%$ water body cover at study area Hjulsta and $10 \%$ cover of discontinuous urban fabric at study area Franska/Kurth, the proportion of all other land cover was below $8 \%$. The number of habitat types in the study areas ranged from 10 to 16 (CORINE land cover (CLC) data level 3) for 110 to 139 habitat patches. No relationship between number of habitats and number of habitat patches was found.

The species number for landscape ( $\gamma$-diversity) ranged from 659 to 1,084 (Table 3). The SRC plantations encompassed 41 to 70 species. The species proportion of $1,600 \mathrm{~m}^{2}$ SRC plantations on $225 \mathrm{~km}^{2}$ of the surrounding landscape varied between 4.6 and $9.0 \%$ (mean, $6.9 \pm 1.7 \%$ standard deviation). The lower the species number of the landscape, the higher was the landscape SRC diversity effect (Fig. 3b, $\left.R^{2}=0.72, p=0.0077\right)$.

Explanatory Variables on $\gamma$-Diversity and Landscape SRC Diversity Effect

The significant model with the best AIC value was the one including all four landscape matrix parameters (Table 4), whereas only the number of habitat types influenced $\gamma$ diversity significantly (Table 5). The $\gamma$-diversity increased with increasing number of habitat types.

Multiple regression models with the response variable 'landscape SRC diversity effect' were calculated for all possible combinations of the variables: SRC plantation age, SRC shoot age, number of habitat types, perimeter-area ratio, percentage area CLC class 2, and percentage area CLC class 3. Two models were significant $(p<0.05)$ and the 'landscape SRC diversity effect' was best explained by the model including the number of habitat types and the SRC shoot age (Table 6). Both the number of habitat types and the SRC shoot age were negatively related to the 'landscape SRC diversity effect' but this was only significant for the number of habitat types (Table 7, overall model: $R^{2}=0.71, p=0.0459$ ). Linear regression analysis resulted in an increasing 'landscape SRC 


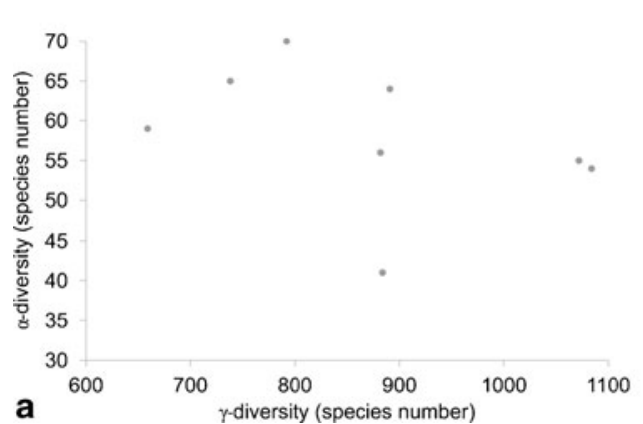

Fig. 3 Relationship of $\alpha$-and $\gamma$-diversity: a scatterplot of SRC species number ( $\alpha$-diversity) and landscape species number ( $\gamma$-diversity) and b linear regression analysis of the landscape SRC diversity effect on $\gamma$ -

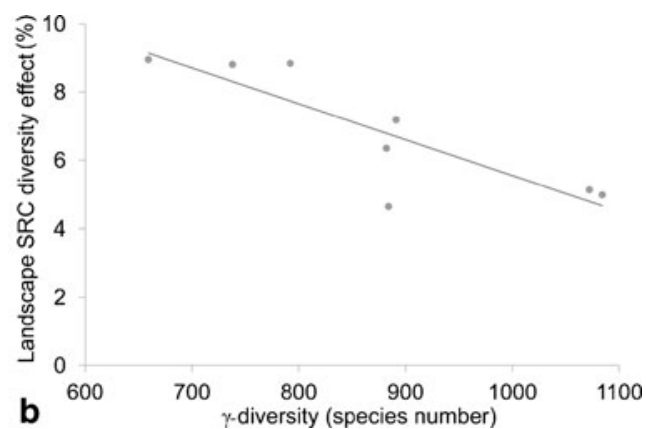

diversity (\%) vs. $\gamma$-diversity. $R^{2}=0.72, p=0.0077$. Regression equation: $y=-0.0105 x+16.08$. Area SRC plantations, $1,600 \mathrm{~m}^{2}$; area landscapes, $225 \mathrm{~km}^{2} ; N=8$

Table 2 CORINE land cover levels and land cover proportions of the study landscapes

\begin{tabular}{|c|c|c|c|c|c|c|c|c|c|c|c|}
\hline CLC code & CLC level 1 & CLC level 2 & CLC level 3 & AS & $\mathrm{BD}$ & $\mathrm{CD}$ & DJ & FK & HS & HT & LB \\
\hline 111 & Artificial surfaces & Urban fabric & Continuous urban fabric & & & & & 1 & & $<0.5$ & \\
\hline 112 & Artificial surfaces & Urban fabric & Discontinuous urban fabric & 2 & 2 & 4 & 1 & 10 & $<0.5$ & 6 & 3 \\
\hline 121 & Artificial surfaces & $\begin{array}{l}\text { Industrial, commercial } \\
\text { and transport units }\end{array}$ & Industrial or commercial units & & & 1 & & 4 & & 1 & 1 \\
\hline 122 & Artificial surfaces & $\begin{array}{l}\text { Industrial, commercial } \\
\text { and transport units }\end{array}$ & $\begin{array}{l}\text { Road and rail networks } \\
\text { and associated land }\end{array}$ & 1 & & & 1 & 1 & & $<0.5$ & $<0.5$ \\
\hline 124 & Artificial surfaces & $\begin{array}{l}\text { Industrial, commercial } \\
\text { and transport units }\end{array}$ & Airports & & & $<0.5$ & & & & $<0.5$ & \\
\hline 131 & Artificial surfaces & $\begin{array}{l}\text { Mine, dump and } \\
\text { construction sites }\end{array}$ & Mineral extraction sites & $<0.5$ & $<0.5$ & $<0.5$ & & & & & \\
\hline 133 & Artificial surfaces & $\begin{array}{l}\text { Mine, dump and } \\
\text { construction sites }\end{array}$ & Construction sites & $<0.5$ & & $<0.5$ & & & & & \\
\hline 141 & Artificial surfaces & $\begin{array}{l}\text { Artificial, non-agricultural } \\
\text { vegetated areas }\end{array}$ & Green urban areas & & & $<0.5$ & & 1 & & $<0.5$ & $<0.5$ \\
\hline 142 & Artificial surfaces & $\begin{array}{l}\text { Artificial, non-agricultural } \\
\text { vegetated areas }\end{array}$ & Sport and leisure facilities & $<0.5$ & $<0.5$ & $<0.5$ & $<0.5$ & 1 & & & $<0.5$ \\
\hline 211 & Agricultural areas & Arable land & Non-irrigated arable land & 57 & 56 & 55 & 58 & 35 & 34 & 46 & 57 \\
\hline 231 & Agricultural areas & Pastures & Pastures & 1 & 3 & 10 & 2 & 1 & 1 & 3 & 2 \\
\hline 242 & Agricultural areas & $\begin{array}{l}\text { Heterogeneous } \\
\text { agricultural areas }\end{array}$ & Complex cultivation patterns & $<0.5$ & $<0.5$ & & $<0.5$ & 1 & 1 & 2 & $<0.5$ \\
\hline 243 & Agricultural areas & $\begin{array}{l}\text { Heterogeneous } \\
\text { agricultural areas }\end{array}$ & $\begin{array}{l}\text { Land principally occupied } \\
\text { by agriculture, with } \\
\text { significant areas of } \\
\text { natural vegetation }\end{array}$ & 1 & 3 & 4 & 1 & 2 & 1 & 4 & 2 \\
\hline 311 & $\begin{array}{l}\text { Forest and semi- } \\
\text { natural areas }\end{array}$ & Forests & Broad-leaved forest & & 3 & 1 & $<0.5$ & 1 & 2 & 2 & \\
\hline 312 & $\begin{array}{l}\text { Forest and semi- } \\
\text { natural areas }\end{array}$ & Forests & Coniferous forest & 26 & 31 & 19 & 25 & 31 & 20 & 31 & 29 \\
\hline 313 & $\begin{array}{l}\text { Forest and semi- } \\
\text { natural areas }\end{array}$ & Forests & Mixed forest & 3 & 1 & 1 & 1 & 3 & 7 & 5 & 1 \\
\hline 324 & $\begin{array}{l}\text { Forest and semi- } \\
\text { natural areas }\end{array}$ & $\begin{array}{l}\text { Scrub and/or herbaceous } \\
\text { vegetation associations }\end{array}$ & Transitional woodland-shrub & 6 & & 1 & 5 & 3 & 3 & & 3 \\
\hline 333 & $\begin{array}{l}\text { Forest and semi- } \\
\text { natural areas }\end{array}$ & $\begin{array}{l}\text { Open spaces with little } \\
\text { or no vegetation }\end{array}$ & Sparsely vegetated areas & & & 1 & & & & & \\
\hline 411 & Wetlands & Inland wetlands & Inland marshes & & & 1 & 1 & & $<0.5$ & & $<0.5$ \\
\hline 511 & Water bodies & Inland waters & Water courses & & & & & $<0.5$ & & & \\
\hline 512 & Water bodies & Inland waters & Water bodies & 1 & & & 2 & 8 & 30 & & \\
\hline
\end{tabular}


Table 3 Diversity of landscapes ( $\gamma$-diversity, $225 \mathrm{~km}^{2}$ ) and SRC plantations $\left(1,600 \mathrm{~m}^{2}\right)$

\begin{tabular}{llrrr}
\hline & & \multicolumn{2}{c}{ Species numbers } & \multicolumn{2}{c}{$\begin{array}{c}\text { Landscape SRC } \\
\text { Country }\end{array}$} & Area and SRC site & SRC & Landscape & Diversity effect (\%) \\
\hline S & Åsby & 70 & 792 & 8.8 \\
D & Bohndorf & 59 & 659 & 9.0 \\
D & Cahnsdorf & 55 & 1,072 & 5.1 \\
S & Djurby & 41 & 884 & 4.6 \\
S & Franska/Kurth & 54 & 1,084 & 4.9 \\
D & Hamerstorf & 56 & 882 & 6.3 \\
S & Hjulsta & 65 & 738 & 8.7 \\
S & Lundby & 64 & 891 & 7.1 \\
\hline
\end{tabular}

$D$ Germany, $S$ Sweden

diversity effect' with decreasing number of habitat types $\left(R^{2}=\right.$ $0.60, p=0.0242$ ).

\section{Plant Communities}

The SRC plantations had a higher proportion of species assigned to plant communities of frequently disturbed and anthropo-zoogenic habitats than landscape species pools. The proportion of species in the plant communities 'herbaceous vegetation of frequently disturbed areas' and 'anthropozoogenic heathlands and lawns' was greatest in both the landscape species pools and the SRC plantations (Fig. 4). The greatest difference between plant communities in the landscape species pools and the SRC plantations occurred for the proportion of 'freshwater and bog vegetation' species, which was $14 \%$ in the landscape species pools and almost

Table 4 Relative goodness-of-fit-test of the multiple Poisson regression models explaining the $\gamma$-diversity: only models with significant variables are shown

\begin{tabular}{lllll}
\hline $\begin{array}{l}\text { Number in } \\
\text { model }\end{array}$ & AIC & SBC & $\begin{array}{l}\text { Variables } \\
\text { in model }\end{array}$ & Significance \\
\hline 1 & 58.4212 & 58.5801 & c & sig \\
2 & 51.4753 & 51.7136 & cd & c sig \\
2 & 51.8684 & 52.1067 & ce & c sig \\
2 & 51.4586 & 51.6969 & cf & c sig \\
3 & 45.9765 & 46.2942 & cde & c sig \\
3 & 45.2899 & 45.6077 & cdf & c sig \\
3 & 44.6970 & 45.0147 & cef & c sig \\
4 & 39.2852 & 39.6824 & c d e f & c sig \\
\hline
\end{tabular}

Response variable: $\gamma$-diversity (species number)

$A I C$ Akaike information criterion, $S B C$ Schwarz criterion, $c$ number of habitat types, $d$ perimeter-area ratio, $e$ percentage area CLC class $2, f$ percentage area CLC class 3, Sig. significant absent in the SRC plantations. 'Deciduous forests and related heathland' species reached $13 \%$ in SRC plantations and $14 \%$ in the landscape species pool. Nineteen percent of the species found in SRC plantations and $8 \%$ of the landscape species pool comprised indifferent species with no real affinity for a particular community. The standard deviations showed that variations between SRC plantations were greater than between landscape species pools.

\section{Discussion}

High Landscape SRC Diversity Effect on $\gamma$-Diversity

The results show that $\alpha$-diversity of small-scale ( $<10$ ha) SRC plantations $\left(1,600 \mathrm{~m}^{2}\right.$ in area) can contribute considerably to plant species richness in larger landscapes $(\gamma$-diversity, $\left.225 \mathrm{~km}^{2}\right)$ accounting for a share of $6.9 \%( \pm 1.7 \% \mathrm{SD}$, Table 3$)$ on average. This is in line with Kroiher et al. [31] who found an 8 to $12 \%$ contribution to landscape species richness when comparing similar-sized SRC stands with landscape units nine times smaller $\left(25 \mathrm{~km}^{2}\right)$. For other land uses (arable land, forests, fallow and grassland), Simmering et al. [11] also found a similar mean share of $10 \%$ of $\alpha$-diversity of different sized patches to $\gamma$-diversity, although these findings related to a considerably smaller agricultural area $\left(0.2 \mathrm{~km}^{2}\right.$ area $)$. The species-area relationship (cf. Fig. 2) indicated a study size of $1,600 \mathrm{~m}^{2}$ per SRC plantation is representative for this type of analysis. In accordance with our results, Kroiher et al. [31] showed the increase in species slowed down rapidly above $200-400 \mathrm{~m}^{2}$ sample area for a poplar SRC plantation in central Germany. We conclude that larger SRC plantations of several hectares on homogenous sites will not result in any further increase in plant species richness and their 'diversity effect' over smaller SRC plantations, and probably rather decrease diversity. Therefore, we recommend planting several smaller SRC plantations instead of one large one, i.e. larger than 10 ha, the maximum plantation size studied here. SRC plantations of different ages, rotation regimes and tree species enhance structural diversity providing habitats for species with different requirements and are thus beneficial for species diversity [50, 51].

Less Species and Habitats in a Landscape Increase the Importance of SRC Plantations for $\gamma$-Diversity

Our study is the first report to show a clear relationship between landscape structure (number of habitat types), $\gamma$ diversity and the contribution of SRC plantations to $\gamma$ diversity across two European landscapes (Fig. 3, Table 7): In accordance with the mosaic concept $[35,36]$, the species number for the landscapes increased with increasing number 
Table 5 Multiple Poisson regression analysis: results of the effect of landscape matrix variables on $\gamma$-diversity

Analysis of maximum likelihood parameter estimates

\begin{tabular}{|c|c|c|c|c|c|c|c|}
\hline \multirow{2}{*}{$\begin{array}{l}\text { Parameter } \\
\text { Intercept }\end{array}$} & \multirow{2}{*}{$\frac{\mathrm{DF}}{1}$} & \multirow{2}{*}{$\begin{array}{r}\text { Estimate } \\
5.9413\end{array}$} & \multirow{2}{*}{$\begin{array}{c}\text { Standard error } \\
0.4992\end{array}$} & \multicolumn{2}{|c|}{ Wald $95 \%$ confidence limits } & \multirow{2}{*}{$\frac{\text { Wald } \chi^{2}}{141.65}$} & \multirow{2}{*}{$\frac{\operatorname{Pr}>\chi^{2}}{<.0001}$} \\
\hline & & & & 4.9629 & 6.9197 & & \\
\hline Number habitat types & 1 & 0.0820 & 0.0130 & 0.0565 & 0.1074 & 39.82 & $<.0001$ \\
\hline $\mathrm{P} / \mathrm{A}$ ratio & 1 & -0.0069 & 0.0143 & -0.0350 & 0.0212 & 0.23 & 0.6295 \\
\hline$(\%)$ CLC 2 & 1 & -0.0011 & 0.0025 & -0.0059 & 0.0038 & 0.18 & 0.6695 \\
\hline (\%) CLC 3 & 1 & 0.0022 & 0.0072 & -0.0118 & 0.0162 & 0.09 & 0.7596 \\
\hline Scale & 0 & 1.6182 & 0.0000 & 1.6182 & 1.6182 & & \\
\hline
\end{tabular}

The scale parameter was estimated by the square root of Pearson's $\chi^{2} / \mathrm{DOF}$

$P / A$ ratio perimeter-area ratio, (\%) CLC percentage surface on landscape area covered by CLC class, CLC class 2 agricultural areas, CLC class 3 forest and semi-natural areas

of habitat types. The more diverse the landscapes and the higher the number of habitat types, the lower was the share of SRC plantations on vascular plant $\gamma$-diversity. This indicates that SRC plantations are most beneficial for flora diversity in rural areas with low habitat type heterogeneity, by providing habitats suitable for many species.

Unlike Poggio et al. [52], who analysed the relationship between the quotient perimeter/area and $\gamma$-diversity in cropped fields and edges, we found no increasing diversity with increasing landscape complexity expressed by the perimeter-to-area ratio. Edges between biotope types often contain a rich flora and fauna $[13,36]$, so that smaller mosaic patches with their comparatively longer ecotones enhance biodiversity of a landscape [36]. Wagner and Edwards [53] showed edges of arable fields and narrow habitats contributing more to species richness than the interior of arable fields and meadows. However, the species present at the edges are intermixed subsets of the adjacent plant communities, and only few species are expected to be present only at edges [13]. We speculate that land cover data on a greater scale than CORINE land cover could provide further information on the relationships between diversity and patch sizes as well as edge lengths. Our results do not confer with one hypothesis of the mosaic concept which claimed the surface proportions of natural, semi-natural and intensely cultivated areas influenced biodiversity, which was also confirmed by Simmering et al. [11]. The landscapes studied here were all dominated by non-irrigated arable land and coniferous forests; all other habitat types comprised only very small percentages of land cover. Thus, the landscapes we analysed may be unsuitable for sound exploration of this hypothesis because only few habitat types dominated the landscapes and their land cover percentages were similar for all landscapes.

SRC Plantations Increase Habitat Variability on Landscape Scale

Due to our study design we were not able to identify plant species that are exclusively found in SRC plantations, since they were also included in the assessments on landscape scale. However, it could be demonstrated that the SRC stands provide a large habitat variability suitable for species of many different plant communities. This becomes apparent particularly when considering the large difference in area between SRC plantations and the landscapes regarded (cf. Fig. 4): three plant communities each contained more than $10 \%$ of the species present (19\% species had no real affinity for a particular community), whereas, in the landscape species pools, the percentage species of four communities accounted for more than $10 \%$. The SRC plantations species composition differs greatly from other land uses common in agricultural landscapes. This was shown by Baum et al. [54] who compared species diversity of arable lands, forests and grasslands and found that species composition of SRC plantations differed especially from arable lands and coniferous forests. SRC

Table 6 Relative goodness-of-fit of the multiple regression models explaining the 'landscape SRC diversity effect': only models with significant variables are shown

\begin{tabular}{|c|c|c|c|c|c|}
\hline Number in model & $R^{2}$ & AIC & SBC & Variables in model & $\mathrm{p}$ model \\
\hline 1 & 0.60 & 5.403 & 5.56185 & SRC shoot age & 0.0242 \\
\hline 2 & 0.71 & 4.8601 & 5.09839 & SRC shoot age, number of habitat types & 0.0459 \\
\hline
\end{tabular}

AIC Akaike information criterion, SBC Schwarz criterion 
Table 7 Parameter estimates of multiple regression analysis modelling the influence of the number of habitat types and the SRC shoot age on the 'landscape SRC diversity effect'

\begin{tabular}{lccc}
\hline Variable & Estimate & Standard error & $\operatorname{Pr}>|\mathrm{t}|$ \\
\hline Intercept & 16.347 & 2.846 & 0.0022 \\
Number habitat types & -0.646 & 0.213 & 0.0291 \\
SRC shoot age & -0.513 & 0.375 & 0.2296 \\
\hline
\end{tabular}

Overall model: $R^{2}=0.71, p=0.0459$

plantations can contribute to landscape diversity by creating new habitats with species composition different from other land uses. Even though SRC plantations are an extensive land use, they contributed mainly to plant diversity by contributing species of disturbed and anthropogenic environments. The proportion of species assigned to plant communities of frequently disturbed and anthropo-zoogenic habitats was higher in SRC plantations than in the landscape species pools. SRC plantations contain predominantly common species and only few studies report the presence of rare species [cf. 25]. Analyses of Baum et al. [54] have shown that SRC plantation age does not affect species number, but species composition. They found a positive relationship between SRC plantation age and SRC tree cover along with a decrease in grassland species proportion and an increase in woodland species proportion. Considering this temporal habitat heterogeneity promoting light-demanding and ruderal species after SRC establishment and rotation cuttings and woodland species later on, SRC plantations can host many different species groups in comparably small areas. The SRC plantations contain a subset of the landscape species pool that comprises on average a share of $6.9 \%$, and by creating new habitats with species composition different from other land uses, these plantations have a high value for landscape diversity.
Our results and those of many other authors (cf. introduction) have shown landscape heterogeneity as beneficial for biodiversity. The expected increase in bioenergy crop production in coming years may have negative effects on biodiversity if it results in the establishment of large monocultures [18, 55]. But, by avoiding large monocultures, planting bioenergy crops can also be an opportunity for increasing structural landscape heterogeneity and creating new habitats which enhance biodiversity in current agricultural landscapes, whereby woodland and SRC plantations are especially beneficial [15].

\section{Conclusion}

Our results show that SRC plantations provide habitats for plants with different requirements and thereby have a significant share on $\gamma$-diversity. Therefore, these plantations positively affect species diversity on the landscape scale, in particular in landscapes with lower habitat diversity. The number of habitat types and the species number in a landscape can be used to predict the contribution of SRC plantations to vascular plant diversity in fragmented agricultural landscapes. Especially in rural areas with low habitat type heterogeneity, SRC plantations are beneficial for plant diversity, where plant diversity enrichment is mainly due to the occurrence of additional species present in disturbed and anthropogenic environments.

CORINE land cover data can be used for landscape structure analyses on higher landscape scales. However, on lower scales, restrictions due to low scale of land-use data must be considered in landscape structure analysis in relation to the mosaic concept: edge effects may be neglected of habitats not distinguished by CLC. Further analyses using consistent land cover information in both Sweden and Germany will be useful
Fig. 4 Mean percentage species proportion assigned to plant communities and standard deviation of the landscapes $\left(225 \mathrm{~km}^{2}, N=8\right)$ and SRC plantations $\left(1,600 \mathrm{~m}^{2}, N=8\right)$. Species proportions were not significantly different between landscape and SRC plantation for 'Woody herbaceous perennials and shrubbery' $(p=0.7213)$ and 'Deciduous forests and related heathlands' $(p=0.6017)$. Significances: ${ }^{*} p<0.05 ; * * p<0.01$; $* * * p<0.001$

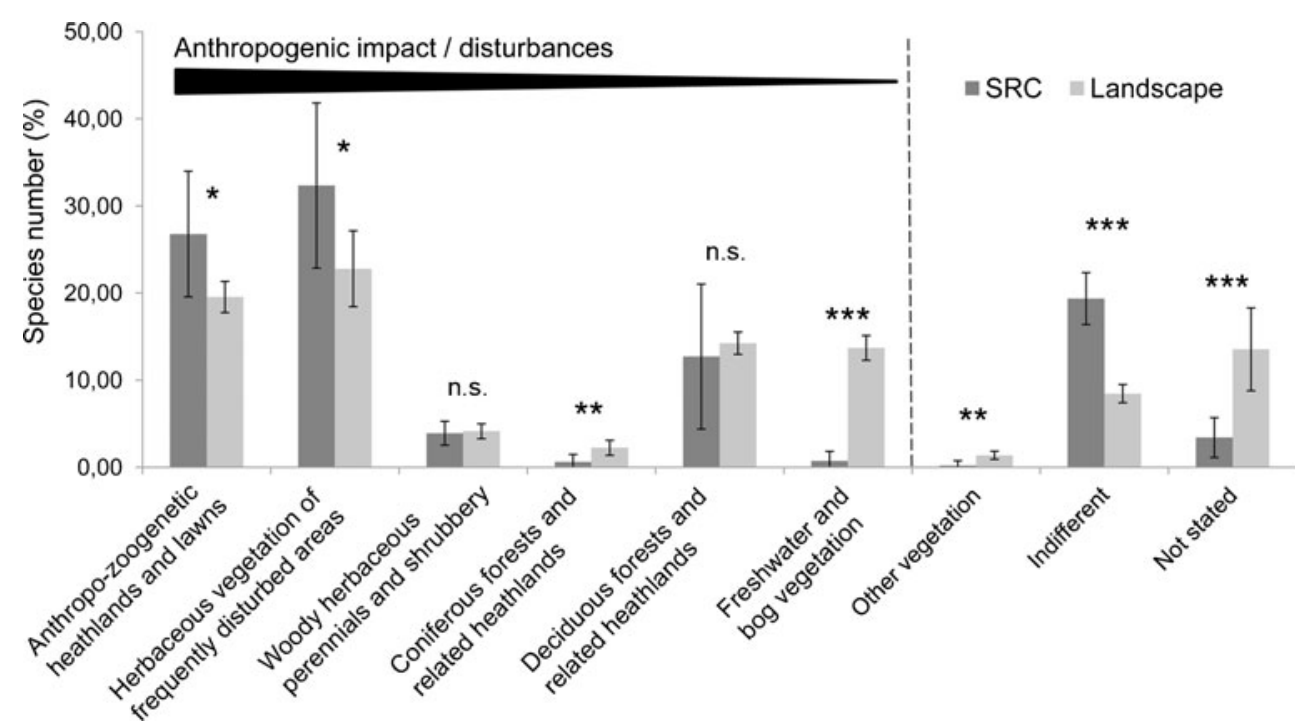


for further detailed landscape structure analyses of SRC plantation effects on landscapes.

Acknowledgements This study was conducted under the framework of the FP7 ERA-Net Bioenergy Project "RATING-SRC" funded by the German Federal Ministry of Food, Agriculture and Consumer Protection (BMELV), the Agency for Renewable Resources (FNR) and the Swedish Energy Agency. We would particularly like to thank Rudolf May from the Federal Agency for Nature Conservation (BfN) and Mora Aronsson from the Swedish Species Information Centre/ArtDatabanken, Swedish University of Agricultural Science (SLU) for providing plant species lists on a higher landscape scale, and also Marieanna Holzhausen and Till Kirchner (vTI Eberswalde) for preparing the geographical data. We thank two anonymous reviewers for constructive comments on an earlier version of this paper.

Open Access This article is distributed under the terms of the Creative Commons Attribution License which permits any use, distribution, and reproduction in any medium, provided the original author(s) and the source are credited.

\section{References}

1. Benton TG, Vickery JA, Wilson JD (2003) Farmland biodiversity: is habitat heterogeneity the key? Trends in Ecology and Evolution 18(4):182-188

2. Firbank LG, Petit S, Smart S, Blain A, Fuller RJ (2008) Assessing the impacts of agricultural intensification on biodiversity: a British perspective. Phil Trans R Soc B 363:777-787

3. Geiger F, Bengtsson J, Berendse F, Weisser WW, Emmerson M, Morales MB et al (2010) Persistent negative effects of pesticides on biodiversity and biological control potential on European farmland. Basic and Applied Ecology 11(2):97-105

4. Mc Laughlin A, Mineau P (1995) The impact of agricultural practices on biodiversity. Agric Ecosyst Environ 55:201-212

5. Tilman D, Fargione J, Wolff B, D'Antonio C, Dobson A, Howarth $\mathrm{R}$ et al (2001) Forecasting agricultural driven global environmental change. Science 292:281-284

6. Whittaker RH (1972) Evolution and measurement of species diversity. Taxon 21:213-251

7. Tuomisto H (2010) A consistent terminology for quantifying species diversity? Yes, it does exist. Oecologia 164:853-860

8. Cousins S (2006) Plant species richness in midfield islets and road verges - the effect of landscape fragmentation. Biol Conserv 127:500-509

9. Ernoult A, Alard D (2011) Species richness of hedgerow habitats in changing agricultural landscapes: are $\alpha$ and $\gamma$-diversity shaped by the same factors? Landsc Ecol 26:683-696

10. Kesting S, Isselstein J (2006) Die Habitat-Heterogenität-Hypothese getestet an einem Sukzessionsgradienten des Grünlands. Bayerische Landesanstalt für Landwirtschaft, Sektion Natur- und Umweltschutz, pp 188-191

11. Simmering D, Waldhardt R, Otte A (2006) Quantifying determinants contributing to plant species richness in mosaic landscapes: single- and multi-patch perspective. Landsc Ecol 21:1233-1251

12. Waldhardt R, Simmering D, Otte A (2004) Estimation and prediction of plant species richness in a mosaic landscape. Landsc Ecol 19:211-226

13. Forman RTT (1997) Land mosaics. The ecology of landscapes and landscapes. Cambridge University Press, Cambridge

14. Berndes G, Hoogwijk M, van den Broek R (2003) The contribution of biomass in the future global energy supply: a review of 17 studies. Biomass Bioenergy 25:1-28
15. Firbank LG (2008) Assessing the ecological impacts of bioenergy projects. Bioenergy Research 1:12-19

16. Offermann R, Seidenberger T, Thrän D, Kaltschmitt M, Zinoviev S, Miertus S (2011) Assessment of global bioenergy potentials. Mitigation and Adaption Strategies for Global Change 16:103-115

17. Valentine J, Clifton-Brown J, Hastings A, Robson P, Allison G, Smith P (2012) Food vs. fuel: the use of land for lignocellulosic 'next generation' energy crops that minimize competition with primary food production. GBC Bioenergy 4:1-19

18. Anderson GQA, Fergusson MJ (2006) Energy from biomass in the UK: sources, processes and biodiversity implications. Ibis 148:180-183

19. Dauber J, Jones MB, Stout JC (2010) The impact of biomass crop cultivation on temperate biodiversity. GCB Bioenergy 2:289-309

20. Eggers J, Tröltzsch K, Falcucci A, Maiorano L, Verburg PH, Framstad E et al (2009) Is biofuel policy harming biodiversity in Europe? GCB Bioenergy 1:18-34

21. Dornburg V, van Vuuren D, van de Ven G et al (2010) Bioenergy revisited: key factors in global potentials of bioenergy. Energy \& Environmental Science 3:258-267

22. EEA (European Environment Agency) (2006) How much bioenergy can Europe produce without harming the environment? EEA Report 7/2006. URL: http://www.eea.europa.eu/publications/ eea_report_2006_7 (visited: 3rd June 2011)

23. Faaij APC (2006) Bio-energy in Europe: changing technology choices. Energy Policy 34:322-342

24. Augustson ÅS, Lind A, Weih M (2006) Floristik mångfald i Salixodlingar. Svenska Botanisk Tidskrift 100:52-58

25. Baum S, Weih M, Busch G, Kroiher F, Bolte A (2009) The impact of short rotation Coppice plantations on phytodiversity. vTI Agriculture and Forestry Research 59(3):163-170

26. Britt CP, Fowbert J, McMillan SD (2007) The ground flora and invertebrate fauna of hybrid poplar plantations: results of ecological monitoring in the PAMUCEAF project. Asp Appl Biol 82:83-90

27. Cunningham MD, Bishop JD, McKay HV, Sage RB (2004) ARBRE monitoring - ecology of short rotation coppice. Four year study involving wildlife monitoring of commercial SRC plantations planted on arable land and arable control plots. URL: http:// www.berr.gov.uk/files/file14870.pdf (visited:3rd June 2011)

28. DTI (Department of Trade and Industry, ed.) (2006) The effects on flora and fauna of converting grassland to short rotation coppice (SRC). URL: http://www.berr.gov.uk/files/file29233.pdf (visited: 3rd June 2011)

29. Fry D, Slater F (2009) The biodiversity of short rotation willow coppice in the Welsh landscape. URL: http://www.willow4wales. co.uk/ (visited: 3rd June 2011)

30. Gustafsson L (1987) Plant conservation aspects of energy forestry-a new type of land use in Sweden. Forest Ecol Manage 21:141-161

31. Kroiher F, Bielefeldt J, Bolte A, Schulter M (2008) Die Phytodiversität in Energieholzbeständen: erste Ergebnisse im Rahmen des Projektes NOVALIS. Archiv für Forstwesen und Landschaftsökologie 42:158-165

32. Schulz U, Brauner O, Gruß H (2009) Animal diversity on shortrotation coppices - a review. vTI Agriculture and Forestry Research 3(59):171-181

33. Weih M, Karacic A, Munkert H, Verwijst T, Diekmann M (2003) Influence of young poplar stands on floristic diversity in agricultural landscapes (Sweden). Basic and Applied Ecology 4:149-156

34. MacArthur RH, Wilson EO (1967) The theory of island biogeography. Princeton University Press, Princeton

35. Duelli P (1992) Mosaikkonzept und Inseltheorie in der Kulturlandschaft. Verhandlungen der Gesellschaft für Ökologie 21:379-383

36. Duelli P (1997) Biodiversity evaluation in agricultural landscapes: an approach at two different scales. Agric Ecosyst Environ 62:81-91

37. German Weather Service (DWD) Download of precipitation and temperature data. URL: http://www.dwd.de/bvbw/appman 
ager/bvbw/dwdwwwDesktop?_nfpb=true\&_pageLabel=_dwd www_klima_umwelt_klimadaten_deutschland\&T82002gs bDocumentPath $=$ Navigation $\% 2$ FOeffentlichkeit $\% 2$ FKlima Um welt $\% 2$ FKlimadaten $\% 2$ Fkldaten_kostenfrei $\% 2$ Fausgabe__mittel werte akt node.html $\% 3 \mathrm{~F}$ nnn\%3Dtrue (visited: 1st July 2010)

38. Swedish Meteorological and Hydrological Institute (SMHI) Download of precipitation and temperature data. Accessed 17 March 2011. URL: http://www.smhi.se/klimatdata/meteorologi/ temperatur/dataserier-med-normalv\% $\%$ C3\%A4rden-1.7354 (visited: 17 March 2011)

39. Whittaker RJ, Willis KJ, Field R (2001) Scale and species richness: towards a general, hierarchical theory of species diversity. J Biogeogr 28:453-470

40. Whittaker RH (1977) Species diversity in land communities. Evol Biol 10:1-67

41. Stoms DM, Estes JE (1993) A remote sensing research agenda for mapping and monitoring biodiversity. Int J Remote Sens 14 (10): $1839-1860$

42. EEA (European Environment Agency) (2000) CORINE land cover technical guide-Addendum 2000. Technical report No 40. URL: http://www.eea.europa.eu/publications/tech40add (visited: 17 August 2011)

43. BfN (Bundesamt für Naturschutz; Federal Agency for Nature Reservation) (2008) Florenkartierung in Deutschland. URL: http://www.bfn.de/0302_florenkartierung.html (visited: 17 August 2011)

44. Jonsell L (ed) (2010) Upplands flora. SBF-förlaget, Uppsala

45. Spektrum Akademischer Verlag, Heidelberg and Berlin, DE

46. Lyman RL, Ames KM (2007) On the use of species-area curves to detect the effects of sample size. J Archaeol Sci 34:1985-1990

47. Scheiner SM (2003) Six types of species-area curves. Glob Ecol Biogeogr 12:441-447
48. Gabriel D, Thies C, Tscharntke T (2005) Local diversity of arable weeds increases with landscape complexity. Perspectives in Plant Ecology, Evolution and Systematics 7:85-93

49. Ellenberg H, Weber HE, Düll R, Wirth V, Werner W (2001) Zeigerwerte von Pflanzen in Mitteleuropa. Skripta Geobotanica 18:1-262

50. Kroiher F, Baum S, Bolte A (2010) Pflanzenvielfalt. In: DBU (ed.) (2010) Kurzumtriebsplantagen. Handlungsempfehlungen zur naturverträglichen Produktion von Energieholz in der Landwirtschaft. Ergebnisse aus dem Projekt NOVALIS. URL: http:/www.dbu.de/ phpTemplates/publikationen/pdf/120410114219pelp.pdf (visited: 17 August 2011)

51. Weih M (ed.) (2008) Short rotation forestry (SRF) on agricultural land and its possibilities for sustainable energy supply. TemaNord 2008:543. http://www.norden.org/en/publications/publications/ 2008-543 (visited: 08 July 2009)

52. Poggio SL, Chaneton EJ, Ghersa CM (2010) Landscape complexity differentially affects alpha, beta, and gamma diversities of plants occurring in fencerows and crop fields. Biol Conserv 143:2477-2486

53. Wagner HH, Edwards PJ (2001) Quantifying habitat specificity to assess the contribution of a patch to species richness at a landscape scale. Landsc Ecol 16:121-131

54. Baum S, Bolte A, Weih M (2012) High value of short rotation coppice plantations for phytodiversity in rural landscapes. GCB Bioenergy. doi:10.1111/j.1757-1707.2012.01162.x

55. Emmerson M, Bourke D, Dauber J et al. (2011) The food versus fuel debate- what effect will replacing traditional crops with Miscanthus $\times$ ginganteus have on farmland biodiversity? In: Ó hUallacháin D \& Finn J (ed.) Conserving farmland biodiversity: Teagasc Biodiversity Conference, lessons learned \& future prospects. Carlow, Ireland: Teagasc Head Office: 58-59 (2011)

56. Colwell RK (2006): EstimateS: statistical estimation of species richness and shared species from samples. Version 8. Persistent URL < purl.oclc.org/estimates> (visited: 11 August 2011) 